10-3-2015

\title{
Resource Sharing Begins at Home: Opportunities for Library Partnerships on a University Campus
}

Robert A. Seal

Loyola University Chicago, rseal@luc.edu

Follow this and additional works at: https://ecommons.luc.edu/lib_facpubs

Part of the Library and Information Science Commons

\section{Recommended Citation}

Seal, Robert. "Resource Sharing Begins at Home: Opportunities for Library Partnerships on a University Campus." presented at the 14th Interlending and Document Supply Conference, Istanbul, October 3, 2015.

This Conference Proceeding is brought to you for free and open access by the Faculty Publications and Other Works by Department at Loyola eCommons. It has been accepted for inclusion in University Libraries: Faculty Publications and Other Works by an authorized administrator of Loyola eCommons. For more information, please contactecommons@luc.edu. (c) $($ ) $(9)$

This work is licensed under a Creative Commons Attribution-Noncommercial-No Derivative Works 3.0 License. (C) 2015 Robert A. Seal. 


\title{
ILDS 2015 Istanbul
}

"Resource Sharing Begins at Home:

Opportunities for library partnerships on a university campus”

Robert A. Seal, Dean of University Libraries

Loyola University Chicago, Chicago, IL, USA

October 3, 2015

\begin{abstract}
Typical discussions of academic library resource sharing focus on activities between and among institutions: interlibrary loan, reciprocal borrowing, document delivery, group acquisitions, etc. But there is another equally important type of cooperation, i.e. working with other campus units to provide better service, more convenience, and enhanced resources for library users. Sometimes referred to as campus collaboration or convergence, this activity also advances institutional priorities, in particular that of student success. Library partners include information technology services, student development, writing centers, academic departments, and centers for teaching excellence, among others. This paper explores these relationships, their advantages and disadvantages, goals, the importance of assessment, project planning, etc. Types of collaboration are presented to illustrate the possibilities. The author concludes by encouraging cooperative activity of this nature, emphasizing the need to collaborate, not compete, with other campus units.
\end{abstract}

\section{Introduction}

\section{A. Overview}

Typical discussions of academic library resource sharing focus on activities between and among institutions: interlibrary loan, reciprocal borrowing, document delivery, group acquisitions, etc. Often overlooked is the significant amount of cooperation that takes place between the library and other campus units. This paper explores such collaboration which is intended to provide better service to constituents as well as to advance university goals and priorities.

Today's higher education environment of declining budgets and increased demand by users means that different campus departments must find ways to work together to efficiently use limited resources while helping faculty and students succeed in teaching and learning. Yet this is not an easy task because as Swartz and her colleagues noted, "Institutions of higher education are complex, decentralized organizations that rely on the specialized knowledge and skill of faculty and staff for most of their day-to-day operations. Although our institutions benefit from this expertise, common drawbacks of such decentralization and specialization include territoriality, "silo" thinking, and the presence across campus of individuals who may be unaware of the talents and interests of professionals in other departments." ${ }^{1}$ However, ".... with a variety of strategies and a positive approach, campus departments and individuals with seemingly disparate objectives can be brought together to accomplish common goals." ${ }^{2}$ Libraries are a key player in this dance of collaboration.

\footnotetext{
${ }^{1}$ Pauline S. Swartz, Brian A. Carlisle, and E. Chisato Uyeki, "Libraries and student affairs: partners for student success,” Reference Services Review 35, no. 2 (2007):109.

2 Ibid., p.110.
} 


\section{ILDS 2015 Istanbul: Robert A. Seal October 3, 2015 \\ Page 2}

We are encouraged to do so by library and university administrators and by our professional associations. Indeed, the Association of College and Research Libraries' (ACRL) Standards for Libraries in Higher Education specifically advises that "Library personnel [should] collaborate with faculty and others regarding ways to incorporate library collections and services into effective education experiences for students." 3 Further, as Ferer notes, "accountability and assessment are becoming more important on college and university campuses and libraries are being asked how they contribute to learning outcomes, recruitment, engagement, and retention both by their administration and by accrediting bodies."4 In large measure, we can achieve success in these important areas by seeking partnerships with other academic units which share our goals of service, convenience, and student success. As we shall see, college and university libraries have done so in a variety of ways, with significant achievement in many instances.

In a study of academic libraries and their interactions with campus partners, Hernon and Powell wrote that "Convergence and collaboration enable an academic library to be more fully engaged with its campus... and to better achieve the educational mission of the library and its parent institution. In its simplest form, convergence is defined as joint activities of a campus's units (e.g. academic departments, information technology (IT), food services, and educational development services) to further their shared mission of supporting teaching, learning, and inquiry." 5 These cooperative activities may include merged departments but more commonly merely involve two or more departments combining experience, human resources, and finances to provide a new or improved service for students and faculty. Libraries, which have cooperated so extensively with each other for decades, are often at the center of campus collaborative activities.

Examples of institutional library cooperation include, but are not limited to, partnerships with

- Tutoring and writing centers

- Information technology

- Centers for teaching excellence

- Student development

- Distance education departments

- Counseling and career centers

- Research centers/centers of excellence and

- Academic units and individual faculty.

\footnotetext{
${ }^{3}$ Association of College \& Research Libraries, Standards for Libraries in Higher Education (Chicago: American Library Association, 2011), paragraph 3.1.

${ }^{4}$ Elise Ferer, "Working together: library and writing center collaboration,” Reference Services Review, 40, no. 4 (2012):543.

${ }^{5}$ Peter Hernon and Ronald R. Powell, eds., Convergence and Collaboration of Campus Information Services (Westport, CT, Libraries Unlimited, 2008), p.xi.
} 


\section{ILDS 2015 Istanbul: Robert A. Seal October 3, 2015 \\ Page 3}

\section{B. Goals}

When libraries collaborate with other campus units, many different goals are achieved. Besides fostering communication among departments and sharing useful information, the primary objective is to help students succeed in their studies and to receive assistance from professionals at the point of need. Hernon and Powell, cited above, reported that the respondents to their survey of academic libraries saw collaboration "as a way for libraries to meet their missions (supporting teaching, learning, and inquiry), serve the entire institution, create new services, promote and improve existing ones, be involved in student learning and the life of the campus, reduce overlap with other campus services, gain more support from the administration, share space and perhaps staff, create multiple points of service (more effective service provision), and increase campus visibility." 6 Whether these were goals in the beginning or simply the benefits of working together is immaterial. The results are a win-win situation for the library, their partners, and their users and, by doing so, librarians demonstrate value while meeting a need for accountability in difficult budget times as well as furthering both the library's and institution's educational mission.

\section{Benefits of campus collaboration}

So why should academic librarians seek partnerships with other colleagues at their institutions? "Collaborating with other campus constituents to create and implement cross-campus programs can provide benefits to a variety of stakeholders. It supports the missions and goals of the collaborating partners, allows for the establishment of a network of colleagues, educates those involved on the programs, service, and goals of other units, and most importantly, promotes success among students."7 Working together combines the expertise and education of professionals in multiple units to meet students' diverse learning needs, study habits, and educational and career goals. Indeed, it takes the entire campus community working together to ensure student success. Through multiple collaborative efforts this objective is met.

Another important benefit of collaboration is raising the visibility of the library on campus in general and among campus administrators in particular. When the library is successful, demonstrates that it is a team player, and exhibits a willingness to support the university mission, greater support may come its way in terms of more funding, additional personnel, and inclusion on campus committees, among other things. While academic libraries already have very good reputations due to their service orientation and innovative programs, by collaborating with other departments they enjoy an even greater level of positive feelings from stakeholders and administrators. Cooperative ventures also raise awareness of the library and its services through referrals by other units. Finally, as Love and Edwards pointed out, "by interacting with our campus and community colleagues through a variety of activities and avenues, we will develop a deeper and richer understanding of the individual, their interests and passions and ultimately

\footnotetext{
${ }^{6}$ Ibid., p.9.

${ }^{7}$ Swartz, “Libraries and student affairs: partners for student success,” p.120.
} 


\section{ILDS 2015 Istanbul: Robert A. Seal \\ October 3, 2015 \\ Page 4}

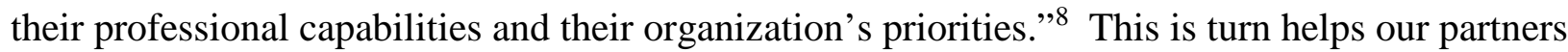
better understand us and the good work we do as information professionals.

\section{Pro's and con's of collaborative activity}

\section{A. Advantages and opportunities}

As noted above, Hernon and Powell refer to the act of working together as "convergence” and in their research investigating this activity at numerous academic libraries they found many advantages as reported by library directors including, but not limited to:

- A more comfortable and convenient learning environment for library users

- Enhancement of student learning and success

- Development of ties with other academic and support services

- Improving user access to information and computer resources

- Integration of library resources into teaching and learning

- Facilitation of new modes of scholar communication such as institutional repositories

- Fulfilling user expectations for seamless, convenient service and extended hours

- Aiding in student retention, an issue of institutional importance, a measurable outcome

- The opportunity to develop creative ways of providing academic services

- An increase in the library's involvement in student learning and campus life

- Obtaining more financial and political support from the university administration

- Consolidation of learning support services

- Development of closer relationships with other campus service units

- More fully integrating learning and technology into the curriculum

- The ability to reallocate resources through merging of departments

- Increased use of library resources and services (and those of library partners)

- Greater status for partners who cooperate. ${ }^{9}$

\section{B. Disadvantages and challenges}

There are other potential advantages and benefits, of course, and the number realized will depend upon the local situation, available resources, and the extent of the willingness to collaborate. In any event, there is little downside to joint services. That does not mean that it is easy to work together all the time. There are real, potential, or perceived disadvantages and challenges. For example, convergence is sometimes harder to manage because it involves multiple budgets and supervisory lines. It therefore requires a different type of coordination and increased communication to be successful. Some librarians might worry about a loss of flexibility when

\footnotetext{
${ }^{8}$ Emily Love and Margaret B. Edwards, "Forging inroads between libraries and academic, multicultural and student services,” Reference Services Review, 37, no. 1 (2009):28.

${ }^{9}$ Hernon, Convergence and Collaboration of Campus Information Services, p.16-31.
} 


\section{ILDS 2015 Istanbul: Robert A. Seal October 3, 2015 Page 5}

working with other departments which can be the case when both units do not equally share responsibility (and credit and blame).

One potential issue is that some administrators expect that the primary purpose of collaboration is to save money. That is usually not the case, in fact, more funds may be required to develop a partnership, especially when services merge. Sometimes there are political issues in the convergence of programs and services, for example when it is proposed to bring non-library units into the library building. If the library is already overcrowded, administrators will understandably be reluctant to have outsiders take up limited, valuable space. Also, certain managers might worry that time spent on cooperative services will conflict with "regular" work when librarians are already overloaded with daily duties, committee assignments, and projects. While this is not an insurmountable obstacle, it is a fact that cannot be ignored in the planning process.

There is also the possibility of "culture shock" when two groups who are not used to working side-by-side now find themselves doing so, especially when each party has a different work style and/or ethic. It can therefore take time for all parties to adjust to a new paradigm. Another challenge can be developing a Memorandum of Understanding (MOU) to clarify each group's responsibilities. This is easier said than done in some instances since certain units, including the library, are reluctant to give up control. Another potential obstacle to cooperation is the fact that librarians and other campus professionals harbor stereotypes and misconceptions about each other as they don't fully understand or appreciate what the other does. But the actual process of collaboration will likely eliminate such thoughts and probably result in increased respect for one another. One should not ignore the aforementioned concerns but neither should one worry too much about the challenges of working together since in the end most problems are solvable.

\section{Factors to consider when evaluating potential partnerships}

Many questions must be answered before proposing a collaborative arrangement. What are the ultimate goals? What perceived needs are not being met? How will a partnership enhance service to students and faculty? Where and when would a new service be offered? What resources will be required? Is there space available in the library or elsewhere on campus? Are there library staff available to undertake the project? Have other institutions tried the idea you have in mind? What problems did they face? These matters and more must be considered before even reaching out to another department. We librarians are known for being good researchers and here we must do the requisite background work before proceeding.

\section{Establishing a relationship}

After the above investigation, there are additional steps to take before embarking on a project of convergence. First and foremost is the need to gain the support of the library's administration which has the ability to commit financial resources and staff time to the endeavor. A written proposal should be prepared in advance of a meeting with one's superiors answering the questions above and outlining a proposed plan of action. The next step is to identify potential 


\section{ILDS 2015 Istanbul: Robert A. Seal October 3, 2015 Page 6}

campus partners. Which units would best meet the needs of the project, i.e. do they have the expertise, experience, and needed resources? Identifying partners requires being aware of current campus priorities, programs, and special projects. This means being active on campus, attending programs, paying attention to campus communications, and making personal contacts. Become familiar with faculty research, visit departmental web sites, collect and read brochures, and attend programs given by individual faculty and their departments. Volunteer to help with new student (and faculty) orientations. In short, know your campus well! In addition, for success in collaboration, the library and its librarians should be well known on campus, not only as a result of involvement outside the building, but also by marketing services, collections, and public programs. Campus departments need to be aware of the broad range of library services and resources if they are to warm up to the idea of a cooperative endeavor.

After a potential partner has been identified and discussions commence, it is important to identify common interests and find places where each department's goals coincide. This sets the stage for developing mutually acceptable objectives. "Agreeing upon, and working toward, shared goals are not only essential to successful collaboration, they are the very essence of collaboration."10 After goals are established to each party's satisfaction, then the process begins to determine the nature of the service, resources needed, responsibilities, and desired outcomes. Such issues must be addressed jointly so that both parties have a vested interest in the endeavor. Next come operational details: hours, staffing, location, technology needed, etc. The Memorandum of Understanding is essential for delineating each side's responsibilities in case of future conflict or misunderstanding. A cautionary note is in order: "Be careful not to make agreements that go beyond the scope of your library's mission or resources. Enthusiasm and eagerness for the collaboration to work can lead to over-commitment. The early establishment of responsibilities, leadership, and well-defined roles for partners, as well as a plan for funding and resource allocation can act as a safeguard against collaborations over-reaching their intended bounds."11 In all types of collaboration, it is recommended to start with a small project, implement it on a trial basis, and evaluate. If things are going well, then the effort can move beyond the test phase and be expanded if desired.

Once a relationship is established and a program initiated, long-term success will depend upon close and regular communication by the project's coordinators. This can be achieved by email, our normal communication tool today, but that is not enough. Regularly scheduled meetings with an agenda are critical, too, as communication is most effective when sitting down together to discuss problems, changes, and new ideas. Depending on the service and its scope, a steering committee of key players should be considered. Regular assessment of the program is a requirement for success and the methodology should be jointly decided upon and implemented. Referrals to each other's department as well as cross listing on each other's website are good ways to work together and to promote each group's services.

\footnotetext{
${ }^{10}$ Swartz, “Libraries and student affairs: partners for student success,” p.119.

11 Ibid.
} 


\section{ILDS 2015 Istanbul: Robert A. Seal October 3, 2015 Page 7}

\section{Elements of success}

As noted in the previous section, a successful collaboration depends on many factors: 1) identifying the right partner; 2) mutual understanding and respect; 3) administrative support; 4) sufficient resources (personnel, space, money, etc.); 5) mutual values and goals; 6) an agreed upon, jointly developed MOU; 7) adequate planning and preparation; 8) regular, close communication and staff meetings; and 9) periodic assessment and course corrections as needed. Depending on the nature of the project or service, other factors will ensure a good outcome, e.g. adequate promotion and marketing, staff personalities, and cross-training. Equally important qualities necessary for cooperation, including some intangibles, are "passion, persistence, playfulness, promotion, and project."12 One might add to this sufficient time and effort. A collaborative program that is not given priority by those involved or lacks enthusiasm will likely fail before it even gets started. Of course, campus politics can also play a role, that is, if the environment is not conducive to departments working together.

Also as Love noted, "the key to collaboration is turning a personal relationship into an organizational partnership." 13 This, of course, is true in many situations in which collaboration is essential to success, whether within the library, a professional organization, or on campus. Close ties with other individuals not only makes it easier to broach the subject of collaboration but also to understand the potential partner's situation, goals, and needs. It is also important to recognize when a project is not working or no longer viable. "What might seem to be antithetical to sustaining a relationship — knowing when the relationship is no longer viable - is an integral part in successful collaboration. If programs and services are not benefiting and partnerships exist only on paper, then the partnership should be allowed to dissolve."14

\section{Importance of assessment}

Assessment in higher education has taken on increased importance in the $21^{\text {st }}$ century and is critical to the long-term success of any library-campus collaboration. "For academic libraries on campus, a fundamental aim of assessment is to demonstrate an alignment with institutional goals for student success."15 ACRL's 2014 “Top trends in academic libraries” supports this notion: "An emphasis on student success outcomes and educational accountability by states, accrediting bodies, and individual institutions, as well as a shift in some states from public higher education funding based on enrollment to funding based on outcomes, such as retention and completion, have implications for academic libraries." 16 Through collaboration with other units, service improves, making it is easier to justify the library's value. No one method of evaluation can be utilized due to the varied nature of projects, departmental differences, available expertise and

\footnotetext{
12 Joni E. Warner and Nancy H. Seamans, “Teaching Centers, Libraries, and Benefits to Both,” Resource Sharing \& Information Networks, 17, no. 1-2 (2008):40.

${ }^{13}$ Love, "Forging inroads between libraries and academic, multicultural and student services," p.24.

${ }^{14}$ Ibid., p.28.

${ }^{15}$ Rachel Besara and Kirsten Kinsley, “Academic libraries - measuring up: assessment and collaboration for student success,” New Library World, 112, no.9/10 (2011):417.

16 “Top trends in academic libraries," C\&RL News, 75, no. 6:297.
} 


\section{ILDS 2015 Istanbul: Robert A. Seal October 3, 2015 Page 8}

experience, etc. In short, it is up to the units and staff involved whether or not to use surveys, statistics, focus groups, or some other method of data gathering and analysis. Whatever the approach, an assessment component must be included in the plan of action for any cooperative endeavor and, most importantly, the outcome must demonstrate that the program has had an impact on student success.

\section{The Information Commons: a model for collaboration}

One of the most common forms of collaboration on university campuses today is the information commons or learning commons. In this model of service, the library usually partners with campus Information Technology (IT) to provide a variety of services, both library and technology, primarily aimed at undergraduates. This cooperation may also extend to involvement by campus writing centers, tutoring, instructional technology, media services, and more. The idea is to create a one-stop-shopping experience for users needing library, technology, and learning support in one convenient location. Longer hours, often 24/5 or even $24 / 7$, are often an important, even sometimes essential feature of an academic commons. The IC service model aims to reduce the need for patrons (mainly students) to travel all over campus to get help. Cross-training of the involved departments helps minimize such referrals.

Schmidt and Kaufman described a primary objective of this service as follows: "The partnership model allows us to apply the combined expertise of librarians, professional staff, and student peer educators to meet students' diverse learning needs, as well as to offer students more coherent and integrated support services"17 They also point out that "The focus of a learning commons goes beyond helping students "manage" information to helping them "manage" their learning." "18 Therefore, the major difference between an information commons (IC) and a learning commons (LC) are services that support student learning. Many IC's have transitioned to the LC model.

Both the IC and LC approach are excellent examples of campus departments working in unison for the benefits of students. They provide places to study, relax, use computers, do research, work with friends, and get help from librarians and technology specialists. The Information Commons at Loyola University Chicago was created with the 3C philosophy of Collaboration, Connectivity, and Community. Collaborative work is a significant part of student learning in the $21^{\text {st }}$ century and the Loyola IC model provides the ideal place for that to happen with group study rooms, large tables, groupings of soft seating, and a café for coffee, work, and conversation. The connectivity component is achieved by hundreds of desktop computers, laptops, and tablets for student use and ubiquitous WiFi throughout the building. Community refers to our vision for a place for students to congregate, whether for work or relaxation, alone or with friends. Our students love to be in the IC for all the above reasons. Other institutions have experienced a similar result to Loyola University Chicago: very high user satisfaction and a dramatically increased number of patron visits.

\footnotetext{
${ }^{17}$ Nancy Schmidt and Janet Kaufman, "Learning commons: Bridging the academic and student affairs divide to enhance learning across campus,” Research Strategies, 20 (2007):243.

${ }^{18}$ Ibid.
} 


\section{ILDS 2015 Istanbul: Robert A. Seal October 3, 2015 Page 9}

The Loyola University Chicago Information Commons also houses the campus writing center and has several teaching spaces in which classes in a variety of disciplines are scheduled from morning into the evening by the University Registrar. The positive advantage of this arrangement is that when classes are over, the students are already in the library where they often stay to do their assignments and receive help from librarians and technology personnel. This creates a positive synergy between pedagogy and library services. The Loyola IT staff maintain the computers, printers, scanners, etc. as well as the wireless network. They also manage a media lab and loan equipment such as digital cameras, video cameras, laptops, headphones, USB cables, tablet computers, microphones, and more. Their staff sit alongside our librarians at the help desk to assist students with technology-related questions.

\section{The Library and Information Technology}

Libraries and campus IT cooperate in other ways, too. Since the majority of library work depends on the computer, university IT staff are needed even when the library has its own computer support personnel. In many cases, campus IT houses and manages library servers, installs and monitors the library's wireless network, handles network communication, and keeps desktop computers and software up-to-date. Collaboration comes into play in a variety of ways beyond the previous example of the Information Commons. Librarians and computer specialists serve on joint committees related to institutional repositories, faculty workshops, scholarly communication, and other topics. On major projects, library and IT staff cooperate and share expertise. A good example of this is when the library acquires a major software package such as an integrated library system (ILS). Here, IT staff can help with specifications and the writing of the RFI or RFP, review security concerns with the library, work together on contracts and negotiating pricing, and advise on other topics. During implementation, their staff assists library IT personnel to create interfaces between the ILS and campus human resources, financial, and student information systems.

\section{The Library and the Writing Center}

“The goals of writing centers and libraries overlap, which makes collaboration between the two units logical. Both services supplement classes and curriculum with the goal to help students succeed in their studies." ${ }^{19}$ Campus writing centers have staff, both professional and student peer tutors, who assist students with writing skills and class assignments such as term papers. They, along with librarians, support freshman "writing intensive" courses which often include an information literacy component as part of their curriculum. In addition to the daily work of helping students write and do research, other types of collaboration between the two partners include workshops for faculty on assignment design, joint tutor training workshops, creating instructional tools and handouts, and serving on joint committees related to instruction. "There are numerous ways for libraries and writing centers to collaborate and improve services to

\footnotetext{
${ }^{19}$ Ferer, “Working together: library and writing center collaboration,” p.544.
} 


\section{ILDS 2015 Istanbul: Robert A. Seal October 3, 2015 Page 10}

students and faculty, but as each educational climate is different it is important to survey the environment before adapting these ideas to your institution."20

Organizationally, writing center programs may fall under the English Department, Academic Services, or Student Affairs. In each case, they provide a natural partnership for libraries since all share the same goal of helping students succeed in their chosen field by improving writing and research skills. At Florida Gulf Coast University (FGCU), the library and writing center collaborated to both increase awareness of each other's expertise and services offered and to identify challenges that both librarians and writing consultants face. Thus, they were able to create collaborative solutions to guiding students through the writing process, helping with understanding assignments, evaluating sources, avoiding plagiarism, and more. ${ }^{21}$ The FGCU partners also conducted a survey to learn how academic writing centers are working with other campus units. Answers included writing center branches in the library (a common occurrence), joint presentations, training writing tutors to provide research assistance, stationing librarians in the writing center, team teaching, helping instructions design assignments, and more. ${ }^{22}$ They and others have learned that working together raises awareness of each other's services and expertise which leads to better service and fewer referrals.

Other types of tutoring are also common on our campuses: mathematics, statistics, biology, and other subjects. A successful late-night tutoring program implemented by the Florida State University Libraries is a good example of a partnership with student government to assist undergraduates at a time convenient for them. ${ }^{23}$ Many schools also provide help with study habits, note-taking, speed reading, and, of course, library research.

\section{The Library and academic departments}

Libraries share a natural affinity with faculty and academic departments in that they all share in teaching and facilitating student learning, and they work cooperatively to promote library resources and explain research methods during bibliographic instruction sessions. Whether a "writing intensive" freshman class or an upper division course for majors, librarians team with professors to make classroom presentations, design assignments involving the use of library resources, team teach classes, and at times even develop curricula.

While much of this cooperation is aimed at so-called mainstream students, there are also special efforts aimed at non-traditional (older), international, and underrepresented (i.e. minority) students. Other courses target first year students who are in the most danger of dropping out ("at risk" students) because they are not well prepared to undertake college courses. These efforts include faculty and librarians but also academic advisors and other staff such as those from the writing center, all working together to help students stay in school and improve grades. This is

\footnotetext{
${ }^{20}$ Ibid., p.553-54.

${ }^{21}$ Rachel Cooke and Carol Bledsoe, "Writing Centers and Libraries: One-Stop

Shopping for Better Term Papers,” The Reference Librarian, 49, no.2 (2008):120

22 Ibid., p.123.

${ }^{23}$ Besara, “Academic libraries - measuring up: assessment and collaboration for student success,” p.419.
} 


\section{ILDS 2015 Istanbul: Robert A. Seal October 3, 2015 Page 11}

challenging because of the wide range of backgrounds and preparation that this diverse group of students represent. An example of an innovative approach to this challenge is at Colorado State University where librarians presented workshops for faculty that "have focused on elements of the teaching experience that are common to all instructors, regardless of the type of students they work with or the duration of their classroom interaction, as well as library-specific topics."24

Librarians partner with faculty in other ways. For example, course management systems (CMS) (Blackboard, Sakai, etc.) allow for links to library resources, and librarians work with teachers to include access to those materials (full-text journal articles, book chapters, e-books, databases) most appropriate for the class in question. This is especially important for distance education classes where students do not have direct access to the physical library. Librarians show faculty teaching online courses how to link to a wide variety of e-resources including video tutorials that will benefit their students in learning how to do research for class assignments. For some universities, subject librarians are noted on CMS pages with their email addresses. Another area of collaboration is joint grant applications for research funding when a librarian and faculty wish to investigate a topic to improve teaching and/or use library resources to enhance student learning. At some universities, librarians are embedded in academic units where they are not only available for help near classrooms and faculty offices but also have an opportunity to better know the professors in their assigned subject fields and to develop possible cooperative projects.

Other examples of library-faculty cooperation include team-teaching in a research methods seminar, co-creating assignments that help students develop critical thinking and advanced writing skills, and training tutors in the use of library resources to complete written assignments. Faculty are often asked to serve on library committees, too. At Loyola University Chicago, professors are important members of our research paper award review committee and they occasionally sit on a search committee to find a new librarian. They have also helped in the planning for the eCommons, our institutional repository, and the committee to undertake a pilot project to test e-textbooks in the classroom. The Loyola University Libraries collaborate with the Graduate School in two areas: writing guidelines for the submission of electronic theses and dissertations and co-presenting of “dissertation boot camps" where PhD students learn how to plan, research, write, and edit their doctoral dissertations.

A recent project of note in which librarians are playing a key role in working with faculty and ensuring student academic success is the Loyola University Chicago’s Arrupe College, a community college within our institution aimed at high school graduates of limited financial means and who for academic reasons are not able to be admitted to the University because of lower than required standardized test scores. The first class of some 160 students, a large majority of whom are Latino or African-American, matriculated in the fall of 2015, and Loyola librarians provided an introduction to the library during students' summer orientation. Other library contributions to this important effort are providing collections in support of the curriculum, creating additional study space in the downtown library near the Arrupe College building, and, providing help with library research and offering library instruction. In short, our

\footnotetext{
${ }^{24}$ Amy Hoseth, "Library participation in a campus-wide teaching program,” Reference Services Review, 37, no.4 (2009):379.
} 


\section{ILDS 2015 Istanbul: Robert A. Seal October 3, 2015 \\ Page 12}

librarians are playing a critical role in the success of this social justice oriented community college.

\section{The Library and Centers for Teaching Excellence}

Universities of all sizes have departments dedicated to helping faculty improve their pedagogical skills. While typically aimed at newer faculty, these so-called centers for teaching excellence (CTE) or faculty development centers not only offer one-on-one consultations but also sponsor workshops of interest to the faculty at large. These can include, but are not limited to, use of media and technology in the classroom, online teaching (increasingly popular), graduate teaching assistant training and orientation, developing syllabi and course outlines, working with course management systems, web development, teaching assessment, identifying plagiarism, etc. The centers also publish newsletters, organize reading or discussion groups around teaching techniques, and assist in the development of new courses.

These and other activities are of great interest to instruction librarians and offer many opportunities for collaboration. Indeed, "there is a natural link between instruction librarians and teaching centers. Many librarians have little or no teaching experience at the time they are asked to participate in library instruction programs. Others do have experience, but are interested in honing their skills." 25 While these teaching excellence units have much to offer our professional staff, librarians can also contribute to the success of the centers. A survey of large research libraries discovered that workshops offered by librarians through CTE's "focused on topics such as course-integrated library instruction, developing better library assignments, information overload, library resources, problem-based learning, and using the Internet." ${ }^{26}$ Librarians also inform faculty about copyright, scholarly communication, and open access publishing; these may be offered in conjunction with the local CTE, indeed many are team taught with those colleagues. Surveys show that most collaborations of this type are initiated by instruction librarians, and teaching center staff are anxious to work with them as they share similar goals and interests. A more recent and highly beneficial collaboration between library and the center for teaching excellence is the latter's course for faculty who have never taught in cyberspace. In these classes, librarians teach units on how to utilize library resources for online classes including how to put links to these materials in the class website or course management page.

\section{The Library and Student Development}

Until relatively recently, there was minimal interaction on many campuses between student development (also known as student affairs) and other university departments including the library. However, this has been changing since around the year 2000, when Art Sandeen, a wellknown leader in student development wrote that "[effective] student affairs leaders know their successes rare come from acting alone. Successes usually occur as the result of close

\footnotetext{
${ }^{25}$ Trudi E. Jacobson, "Perspectives on...Partnerships between library instruction units and campus teaching centers,” Journal of Academic Librarianship, 27, no. 4 (2001):2.

${ }^{26}$ Ibid., p.3.
} 


\section{ILDS 2015 Istanbul: Robert A. Seal October 3, 2015 Page 13}

collaboration and planning with key colleagues on the campus, most of whom are not in student affairs."27 Even so, there are challenges to effective cooperation with student development. They are not aware of the roles, responsibilities, and skills of other campus units so it does not always occur to them to think about collaboration. Forrest noted that "Student affairs professionals may feel that students' lives outside the classroom are their [emphasis added] responsibility."28

Further, Student Affairs is a complex unit with many responsibilities including housing, meals, discipline, student government, health care and wellness, intramurals, new student orientation, diversity affairs, programming, international students, and more. Therefore, when one collaborates with Student Affairs, it most likely means working with just one part of a large division. In addition, student development work often attracts younger employees, often recent college graduates, who either change positions or move on to other institutions in search of career advancement. This frequent turnover can work against establishing long-term relationships.

Yet partnerships with libraries can and do occur since the university library and the dean of students office share a similar goal, one stated many times already-student success. Forrest also noted that "In addition to the primary goal of supporting student learning, both academic librarians and student affairs professionals are advocates for all the students at their institutions so it seems natural that a partnership should develop." ${ }^{29}$ A common area of collaboration is that of promoting and ensuring academic integrity because of concerns about plagiarism and other types of educational dishonesty. As a result, librarians sometimes work with student development professionals to develop workshops and tutorials to raise student awareness of these issues.

Other areas of collaboration focus on co-curricular activities. "First-year experience programs, leadership initiatives, learning communities, and service learning opportunities are some examples of programs that engage faculty, staff, and students as partners in creating purposeful learning activities." 30 Librarians are frequent participants in such undertakings, lending their expertise in a variety of ways as mentors, volunteers, and partners. Other areas where librarians collaborate with student development staff include tutoring, writing and presentation skills, citation methods, research help, etc.

Because of multiple library-initiated partnerships with student development, librarians have proven their value to the academic enterprise and student success. "Both librarians and student affairs professionals are motivated by a strong commitment to service and are involved in providing a range of programs and resources to students at the undergraduate and graduate levels. Both units serve as instructional centers on campus by helping students and faculty inside

\footnotetext{
${ }^{27}$ Swartz, "Libraries and student affairs: partners for student success,” p.110.

${ }^{28}$ Laura Urbanski Forrest, “Academic Librarians and Student Affairs Professionals: An Ethical Collaboration for Higher Education,” Education Libraries, 28, no. 1 (2005):3.

${ }^{29}$ Ibid., p.2.

30 Schmidt, "Learning commons: Bridging the academic and student affairs divide to enhance learning across campus,”p.242.
} 


\section{ILDS 2015 Istanbul: Robert A. Seal October 3, 2015 Page 14}

and outside the classroom."31 In short, "Libraries and student service professionals are well situated to facilitate students' transitions to informed citizens."32 At Loyola University Chicago, our motto is "preparing people to lead extraordinary lives." Our librarians play an important role in fulfilling that lofty goal, working in partnership with Student Development and other campus departments.

\section{The Library and other campus units}

In addition to the most common and impactful collaborations cited above, there are, of course, many other examples of library-campus cooperation. These include 1) digital humanities programs working with Special Collections staff to scan, analyze, and study rare books, broadsides, and manuscripts; 2) Alumni Affairs for joint cultural programming and library services for graduates; 3) Athletics where librarians offer tutoring and study skills support for student-athletes; 4) building library collections in support of offices of diversity and multicultural affairs who in turn offer workshops for library staff to better understand the needs of LGBTQ students and students of color; 5) Instructional Technology for developing joint programs incorporating library and computer resources into the curriculum; 6) University Advancement for shared fundraising efforts and public programming; 7) Office of Sponsored Research on developing grant proposals; 8) facilities departments in developing space plans for library renovations, expansions, and new buildings; 9) providing spaces, technology, and research help in support of students with disabilities; and many more. The reader no doubt can cite numerous examples on their own campuses, all of which are aimed at improving service to the university community.

\section{Conclusion}

As demonstrated above, libraries have initiated and participated in a wide variety of cooperative projects with campus partners which share our goals. We librarians have realized the benefits of cooperation from our long history of resource sharing with other institutions and have applied many of the same practices and philosophy to developing on-campus collaborative ventures. While both internal and external types of collaboration benefit the university community, it is the former that directly impacts the success of student learning and career development. All academic libraries should consider initiating projects and services with campus partners for the benefit of our students' education and personal development. "Creating strategic partnerships on campus is not the only way to address the changing needs of our students, but could very easily become imperative as the many components of a student's life blend together and our traditional services are no longer relevant, let alone, appealing to students." ${ }^{33}$ In the end, we librarians must think beyond ourselves and our own resources and services to the advantages of working with other campus units, realizing that by joining forces we accomplish more for our students and faculty. Let's be collaborative, not competitive!

\footnotetext{
${ }^{31}$ Schmidt, "Learning commons: Bridging the academic and student affairs divide to enhance learning across campus,” p.246.

32 Love, "Forging inroads between libraries and academic, multicultural and student services,” p.21.

33 Ibid., p.28.
} 